\author{
Barbara Batko, Barbara Trzaska \\ Wyższa Szkoła Ekonomiczno-Humanistyczna w Bielsku-Białej
}

\title{
ODPOWIEDZIALNOŚĆ KADR ADMINISTRACJI PUBLICZNEJ W BUDOWANIU SPOŁECZEŃSTWA INFORMACYJNEGO W POLSCE
}

\section{Kodeks etyki pracownika administracji publicznej}

Problem odpowiedzialności pracowników administracji publicznej ma charakter wieloaspektowy. Można go rozpatrywać w kategoriach filozoficznych (szczególnie w obszarze aksjologii i etyki), prawnych, społecznych, ekonomicznych, a nawet bezpieczeństwa państwa. Odpowiedzialność pracowników jest immanentną cechą zatrudnionych $w$ tym sektorze i może byś rozpatrywana w kontekście etycznym. Jest również ważkim atrybutem organizacji zatrudniającej, wpływającym na jej wizerunek. Egzekwowanie odpowiedzialności, czy nawet wymuszanie jej jest niezbędne i wymaga sankcjonowania. Ze względu na temat podjęty w artykule, za punkt wyjścia do rozważań przyjęto etykę.

Etyka często jest utożsamiana z moralnością, lecz nie można używać tych pojęć jako synonimów. Etyka to dział filozofii zajmujący się opisem i badaniem moralności, dociekaniem przyczyn ludzkich zachowań, źródeł moralności i ustalaniem norm moralnego postępowania. To także przyjęty $\mathrm{w}$ danej zbiorowości i w określonym czasie ogół zasad postępowania [Dubisz: 2003: 858; Tokarski: 1980: 203]. Sama zaś moralność to przyjęty w społeczeństwie zespół norm i zachowań oraz wzorów postępowania i ideałów osobowych moralnych, oceniany wg określonego społecznie funkcjonującego systemu ocen i norm [Dubisz: 2003: 157; Tokarski: 1980: 491]. Etyka wpływa na wartości przyjęte i przestrzegane $\mathrm{w}$ organizacji, jaką jest administracja publiczna. Jedną z tych wartości jest odpowiedzialność zatrudnionych pracowników za swoją postawę w relacjach z interesariuszami (obywatelami) oraz za świadomą realizację zadań wynikających z określonego stanowiska pracy, zgodnie z przyjętymi procedurami, w ramach obowiązującego ładu prawnego. 
Według ujęcia klasycznego rola starej administracji polega na wykonywaniu przepisów określonych prawem, wydawaniu decyzji i kontroli ich legalności. Administracja nie jest aktywnym uczestnikiem rynku usług. Administracja publiczna pełni służebną rolę wobec społeczeństwa, która zasadza się na biernym świadczeniu usług państwu i obywatelom. Administracja publiczna - według Izdebskiego [2007: 8] zawsze oznacza stużbę lub działalność wykonawcza, wykonywanq w stosunku do kogoś lub czegoś ważniejszego, zwierzchniego, decydujacego. Jest instrumentem stużacym do osiagania celu, który w założeniu nie jest jej własnym celem, lub wykonywania woli zwierzchnika. Ów zwierzchnik należy przy tym, w całości albo w części, do innego porzqdku - porzadku politycznego, porzadku władzy politycznej, instytucjonalnie usytuowanej $w$ systemie władz publicznych (państwie $w$ znaczeniu szerszym, państwo $w$ ścistym znaczeniu nie obejmuje bowiem instytucji samorzqdu).

$\mathrm{Na}$ administrację publiczną trzeba jednak spojrzeć szerzej niż poprzez świadczącą usługi publiczne służebną organizację będącą „osią” procesu. Należy nawiązać do współczesnych lansowanych od lat 80. ubiegłego wieku koncepcji New Public Management (NPM) i Public Governance (PG). NPM kładzie nacisk na obywatela jako konsumenta usług publicznych, outsourcing, wyniki, jakość itd. PG na partycypacyjny proces zarządzania społeczeństwem z udziałem innych podmiotów sektora publicznego i prywatnego. Public Governance widzi obywateli i ich grupy nie jako konsumentów, ale jako podmioty decyzyjne lub też świadome i zainteresowane decyzjami władz publicznych. Interesariusze ci współuczestniczą $\mathrm{w}$ zaradzaniu publicznym $\mathrm{w}$ możliwie jak największym stopniu. Administracja publiczna w rozumieniu governance jest elementem demokracji uczestniczącej. Jest organizacją interaktywną, partnerską, prowadząca dialog ze społeczeństwem, z akcentem na zachowania etyczne organizacji. Istotne jest powierzanie zadań publicznych instytucjom społeczeństwa obywatelskiego z zachowaniem publicznej odpowiedzialności za prawidłową realizację tych zadań przez władze [ibidem: 14 i dalsze; szerzej: Kowalczyk, 2008].

Między nurtami i odmianami w łonie NZP oraz PG istnieje sporo różnic, które zostały tu z konieczności zupełnie pominięte. Mimo tego D. F. Kettl traktuje NPM jako spójny model governance. Dzieje się tak ze względu na wspólne założenia i podstawowe podobieństwa, a przede wszystkim przedmiot, którym są relacje pomiędzy rządem i społeczeństwem. Good Governance (sorting out of mission, role, capacity and relationships) jest warunkiem koniecznym, lecz niewystarczającym dla dobrej koniunktury gospodarczej i stabilizacji społecznej [Kettl: 2000: 6]. D. F. Kettl wyróżnia w NZP sześć podstawowych celów działania administracji [ibidem: 1-2]. Są to:

1) wydajność (productivity) - przy wzroście wydajności rząd może utrzymać czy nawet poszerzyć zakres usług publicznych przy zmniejszonych zasobach finansowych, 
2) urynkowienie (marketization) - wykorzystanie przez rząd z mechanizmów rynkowych w celu zwiększenia konkurencyjności tradycyjnych nakazowo-kontrolnych struktur biurokratycznych,

3) orientacja na usługi (service orientation) - wzmocnienie powiązań pomiędzy rządem a obywatelami i poprawa zadowolenia obywateli - odbiorców usług publicznych, co w efekcie prowadzi do wzrostu zaufania do samej organizacji rządowych,

4) decentralizacja (decentralization) - według koncepcji NPM, rząd powinien być bliżej obywateli, po to by jego działania lepiej korespondowały z potrzebami obywateli,

5) polityka (policy) - dążenie do polepszenia wydajności usług publicznych i zwiększenia ich siły nabywczej,

6) odpowiedzialność za wyniki (accountability for results) - NPM kładzie nacisk na potrzebę dotrzymywania obietnic składanych przez rząd, czyli ich realizację.

Administracja publiczna działa w otoczeniu, $\mathrm{z}$ którym wchodzi w rozmaite relacje. Otoczenie to system $\mathrm{z}$ wieloma podsystemami: prawnym, politycznym i gospodarki rynkowej oraz społeczeństwem obywatelskim [Izdebski: 2007: 9 i dalsze; także Krajewski: 2000/2001: 111] wymienia szereg uwarunkowań zachowań etycznych instytucji publicznej: czynniki zewnętrzne i wewnętrzne. Do zewnętrznych należą system społeczno-gospodarczy, prawny, aktualna sytuacja polityczna, a także obowiązujący w danym społeczeństwie zestaw norm i obyczajów. Czynnikami wewnętrznymi będą m. in.: misja organizacji, jej polityka wewnętrzna, kultura organizacji, a więc i poziom moralny urzędników. Owe podsystemy wywierają na siebie wpływ i kreują określone zachowania, w tym zachowania etyczne.

W myśl koncepcji New Public Management (NPM) i Public Governance (PG) urzędnik administracji publicznej wykonuje obowiązki rzetelnie - pracuje sumiennie, dążąc do osiagnięcia najlepszych rezultatów swej pracy, zgodnie z wymogami ,dobrej roboty” - wnikliwie i rozważnie. Winien być innowacyjny, czyli twórczy i aktywny, ale także poczynać zgodnie z prawem i przewidzianym trybem działania [Boć: 2003: 275-277]. Te działania więc powinny prowadzić do świadczenia usług wysokiej jakości. Na jakość usług należy patrzeć przez pryzmaty etyki. Według W. Gasparskiego [2000] jakość ma wymiar etyczny:

- od jakości wyrobu i/albo ustugi zależy reputacja organizacji;

- jakość wyrobu i/albo ustugi jest pochodna jakości zorganizowania firmy;

- jakość zorganizowania zależy od chemizmu spoteczności tworzqcej organizacje oraz od zorkiestrowania działań - podejmowanych decyzji - członków organizacji;

- chemizm organizacji zależy od kultury organizacyjnej, ta zaś od wartości, na jakich ufundowana jest etyka organizacji; 
- przypadki ztego zachowania sq pochodna faktu, że nieetyczne zachowania maja częstokroć charakter systemowy.

Etyka organizacji administracji publicznej powinna być ujęta w ramy kodeksu etycznego, który w dużym stopniu kształtowałby etos pracy urzędników. Kodeks to zbiór usystematyzowanych i opartych na wspólnych zasadach przepisów, dotyczących jednej gałęzi prawa i regulujący jedną dziedzinę stosunków społecznych. Jest to także zespół norm, reguł, zasad, przepisów, często zwyczajowych, dotyczących jakiejś dziedziny, np. Kodeks obyczajów czy Kodeks etyki lekarskiej [Tokarski: 1980: 361] Kodeksy etyczne to katalogi standardów zachowań etycznych, kanonów określających sposób postępowania pracowników i służących ocenie ich pracy. Pełnią przede wszystkim, funkcję doradczą - informacyjną i edukacyjną, ale także funkcję kontrolną, ponieważ formułują i upowszechniają standardy zachowań etycznych [por. Gasparski: 2000: 131138].

W Polsce brak jednak zapisów prawnych regulujących zbiór wartości moralnych, które dotyczyłyby zachowań i postępowania pracowników administracji publicznej. Są kodeksy szczegółowe normujące zachowania wybranych sfer działań: Kodeks Etyki Służby Cywilnej (w skład służby cywilnej nie wchodzą pracownicy samorządu terytorialnego), Zasad Etyki Poselskiej, Kodeksu Etyki Funkcjonariusza Służby Celnej, nie ma zaś jednego kodeksu dla administracji publicznej samorządowej - do tego służą regulacje lokalne.

Kodeks Etyki Służby Cywilnej ma na celu ustanowienie standardów postępowania, których powinni przestrzegać urzędnicy i pracownicy stużby cywilnej, oraz wspomagania ich $w$ prawidtowym wypetnianiu tych standardów, $w$ zgodzie z oczekiwaniami społecznymi i obywatelskimi [Zarzadzenie nr 114 Prezesa Rady Ministrów z 11 października 2002 r.].

Kodeks ów został oparty o zapisy Konstytucji RP [Konstytucja Rzeczypospolitej Polskiej z dnia 2 kwietnia $1997 \mathrm{r}$.] oraz o uchylone już ustawy o służbie cywilnej [Ustawa z dnia 18 grudnia 1998 r.; Ustawa z dnia 24 sierpnia 2006 r.]. Ustawa konstytucyjna określa Rzeczpospolitą Polską jako demokratyczne państwo prawne [Konstytucja Rzeczypospolitej Polskiej...: art. 2], w którym organy władzy publicznej działaja na podstawie i w granicach prawa [ibidem: art. 7]. Ustawa o służbie cywilnej obliguje urzędnika do złożenia uroczystego ślubowania: Ślubuje stużyć Państwu Polskiemu, przestrzegać Konstytucji Rzeczypospolitej Polskiej, wykonywać obowiazki urzędnika stużby cywilnej sumiennie $i$ bezstronnie, zgodnie z najlepsza wiedzq $i$ wola [Ustawa z dnia 18 grudnia 1998 r.: art. 39; Ustawa z dnia 24 sierpnia 2006 r.: art. 29]. Ustawa normując obowiązki urzędnika służby cywilnej - na pierwszym miejscu stawia obowiązek przestrzegania Konstytucji RP i innych przepisów prawa, ochronę interesów państwa i obywatela, racjonalne gospodarowanie zasobami publicznymi, z dbałością o nie, rzetelne i bezstronne, sprawne i terminowe wykonywanie zadań, a także rozwijanie własnej wiedzy zawodowej i godne zachowanie [Ustawa $z$ dnia 
18 grudnia 1998 r.: Rozdziat 6. Obowiazki członka korpusu stużby cywilnej: art. 67; Ustawa z dnia 24 sierpnia 2006 r.: art. 47]. Zapisy te ujęto w Kodeksie Etyki Służby Cywilnej.

Sam Kodeks Etyki Służby Cywilnej wskazuje także na to, iż członek korpusu służby cywilnej działa tak, aby jego działania mogły być wzorem praworządności i prowadziły do pogłębienia zaufania obywateli do państwa i jego organów; winien wykonywać pracę z poszanowaniem godności innych i poczuciem godności własnej; swoim działaniem winien współtworzyć wizerunek służby cywilnej. Podkreśla się tu rzetelność w podejściu do obowiązków służbowych, a w szczególności: sumienność, twórcze i aktywne podejmowanie zadań, wnikliwość i rozwagę, najlepszą wolę, dotrzymywanie zobowiązań, kierując się prawem i przewidzianym trybem działania. Za istotny wskazano tu rozwój wiedzy zawodowej, dążność do pełnej znajomości aktów prawnych oraz okoliczności spraw, gotowość do wykorzystania wiedzy współpracowników oraz do korzystania z pomocy ekspertów, dbałość o jakość merytoryczna, rzeczowość. Bezstronność w wykonywaniu zadań i obowiązków przejawiać się winna $\mathrm{w} \mathrm{m}$. in. równouprawnieniu $\mathrm{w}$ traktowaniu podmiotów i poszanowaniu prawa obywateli do informacji, mając na względzie jawność działania administracji publicznej [Załącznik do Zarzqdzenia nr 114 Prezesa Rady Ministrów z 11 października 2002 r.: § 1, 2, 3, 4].

Na marginesie trzeba zauważyć, że Kodeks Etyki Służby Cywilnej ma charakter prawa miękkiego. Zarządzenie powołano bez upoważnienia ustawowego, ponieważ takiej podstawy prawnej wówczas nie było. Istniały jedynie zalecenia - Rekomendacja Komitetu Rady Ministrów Rady Europy nr R/2000/10 z dnia 11 maja 2000 r. $w$ sprawie kodeksu postępowania urzędników w stużbie publicz$n e j$. Obecnie, godnie z obowiązującym prawem, Prezes Rady Ministrów winien określić w drodze zarządzenia zasady etyki korpusu służby cywilnej, ponieważ zarządzeniem tym nie staje się automatycznie Zarzqdzenie $n r$ 114... [Ustawa $z$ dnia 21 listopada 2008 r.: art. 15, ust. 10]. Uznać je w zwiazku z tym trzeba byto $z a$, wprawdzie nietypowy, bo deklaratoryjny, zwykty akt kierownictwa wewnętrznego o charakterze soft law - niebędacy kwalifikowanym aktem kierownictwa, tj. źródtem prawa o mocy wewnętrznie obowiqzujacej [Izdebski: 2010: 19-20].

Istniejący w UE Europejski Kodeks Dobrej Administracji z 6 października 2001 r. przyjęty przez Parlament Europejski w Polsce nie obowiązuje. Kodeks został opracowany przez Jacoba Södermanna ombudsmana Unii Europejskiej, a Parlament Europejski zalecił we wrześniu 2001 r. stosowanie Kodeksu w organach i instytucjach Unii. Kodeks Dobrej Administracji można traktować jako zbiór standardów przydatnych także poza granicami Unii do oceny funkcjonowania administracji, a powinno się je stosować w Polsce, która funkcjonuje w ramach struktur unijnych od sześciu lat.

Jak pisze Rzecznik Praw Obywatelskich A. Zoll [2002: 5]: prawem $i$ to podstawowym obywatela Unii Europejskiej jest domaganie się od organów i in- 
stytucji Unii bezstronnego zgodnego z prawem rozpatrzenia, bez zbędnej zwtoki, sprawy wniesionej do danego organu lub instytucji. Prawu temu towarzyszy obowiazek organów $i$ instytucji, a także wszystkich zatrudnionych $w$ nich funkcjonariuszy, wtaściwego, zgodnego z prawem obywatela zatatwienia sprawy. (...) Można bytoby powiedzieć, że jest to zupetnie oczywiste. Tak, to powinno być oczywiste, ale dopóki pomiędzy powinnościq i rzeczywistościq zachodzi znaczna różnica, to jest konieczne state przypominanie administracji jej obowiazków i uświadamianie obywatelom ich praw. (...) Nie ma żadnych powodów przemawiajqcych przeciwko uznaniu standardów zawartych $w$ Kodeksie za przydatne do wyznaczania obowiazków polskiej administracji. (...) Ma to znaczenie dla przystosowania codziennych kontaktów obywatela z urzędem do wymogów stawianych $w$ Unii Europejskiej. Trudno zaprzeczyć, że na tym polu mamy nieco do zrobienia.

Często owe zapisy nie mają w praktyce żadnego ciężaru gatunkowego, choć misją urzędnika jest służba publiczna z przyświecającą mu zasadą przestrzegania norm i reguł zawartych w kodeksie etyki. Praca w zgodzie $\mathrm{z}$ oczekiwaniami społecznymi i obywatelskimi.

\section{Wiarygodność instytucji administracji publicznej a jej wizerunek}

Państwo polskie deklaruje wagę transformacji społeczeństwa industrialnego w nowoczesne społeczeństwo informacyjne. Działania państwa polskiego w budowaniu i rozwoju społeczeństwa informacyjnego mają dziesięcioletnią tradycję. Obecne cele państwa polskiego, tak jak je definiuje rząd polski, to: budowa dobrobytu, dynamiczny, zrównoważony rozwój, bezpieczeństwo kraju i obywateli oraz budowanie zaufania społecznego i dumy narodowej, w tym: edukacja obywatelska, rozwój społeczeństwa obywatelskiego, poprawa wiarygodności instytucji publicznych oraz budowa wizerunku Polski [Strategiczny plan rzqdzenia].

Termin „społeczeństwo informacyjne” przyjął się w oficjalnych dokumentach Unii Europejskiej w połowie lat 90., aczkolwiek wprowadzony został w 1963 r. przez Japończyka Tadao Umesao w artykule o teorii ewolucji społeczeństwa opartego na ,przemysłach informacyjnych”, a spopularyzowany przez Kenichi Koyamę w opublikowanej 1968 r. po japońsku rozprawie pt. Wprowadzenie do teorii informacji (Introduction to Information Theory) [za: Goban-Klas: 2001: 286]. Już w 1972 r. opracowano kompleksowy plan rozwoju sektora informatycznego i telekomunikacyjnego w celu zapewnienia rozwoju życia społecznego Japonii. Plan zakładał kompleksowy i strategiczny rozwój sfery życia - od komputeryzacji nauki, poprzez komputeryzację zarządzania w organizacji, informacji społecznej, do komputeryzacji działań jednostkowych, obejmując kolejno coraz węższe i bardziej subtelne kręgi: państwo, organizacje 
i instytucje, społeczeństwo i wreszcie jednostkę - obywatela. Zakładane działania miały wymierne cele - od wzmocnienia obronności i rozwoju oraz badań, poprzez wzrost PNB, dobrobytu i opieki społecznej do osiagnięcia zadowolenia przez jednostkę, kreując takie wartości jak: prestiż narodowy, wzrost gospodarczy, dobrobyt społeczny i rozwój osobowości jednostki. Była to realna strategia, obejmująca kompleksową informatyzacje, prowadzącą do rozwoju intelektualnego kraju oraz tworzenia wiedzy [ibidem: 287]. Trzeba zauważyć, że okres rozwoju komputeryzacji i społeczeństwa informacyjnego obejmował około pół wieku i tylko długofalowe, czyli strategiczne działanie mogło doprowadzić do sukcesu, czyli realizacji wiązki celów strategicznych. Należy to zaakcentować, ponieważ w Polsce „strategie rozwoju” zakładają okres kilkunastoletni, lecz często po zmianie rządu, zostają zarzucone, a podjęte działania nie są kontynuowane. Brak ciągłości działań i towarzyszące im często głębokie zmiany strukturalne organizacji sektora publicznego przez kolejne koalicje rządzące nie może doprowadzić do spełnienia żadnego z celów strategicznych. Efektem takich działań jest marnotrawstwo wysiłku intelektualnego twórców strategii i ogromnych nakładów finansowych pochodzących nie tylko z budżetu państwa.

Każda organizacja, a więc także instytucja administracji publicznej, powinna się charakteryzować wiarygodnością. Wiarygodność można ująć jako rzetelność, bezstronność i uczciwość, a także kompetencje wynikające z wiedzy i doświadczenia, które to walory ujęte są we wspomnianych wyżej ustawach i kodeksach. Na wiarygodność organizacji składa się wiarygodność pracujących w niej ludzi oraz ich spójne działania, które przekładają się na wizerunek instytucji.

Istotną w tym rolę odgrywają dokładne informacje o instytucjach sektora publicznego, które rząd gromadzi i publikuje. Publikując rzetelne informacje buduja zaufanie społeczeństwa, poprzez czytelne i przewidywalne zachowania jego organów. Instytucje publiczne podejmują działania by przekonać społeczeństwo o swym nienagannym działaniu - instytucjonalnej odpowiedzialności. Ważne jest, aby ich działania były rozpoznawane jako etyczne. Zaufanie jest niezbędną przesłanką działalności realizowanej przez instytucje publiczne. Wiarygodność wypływająca z klarownych norm społecznych i etycznych prowadzi do rzetelnego i uczciwego traktowania obywatela.

W przekazywaniu informacji o działaniach państwa niebagatelną rolę odgrywa Internet. Internet staje się coraz bardziej dostępny i pożądany przez obywateli, a państwo ze swej strony podkreśla dużą wagę tego medium w komunikacji między organizacjami a obywatelami. Działania państwa to między innymi realizowanie określonych misji społecznych, pozwalających odbiorcy na zaspokojenie ciekawości i uczenie się, czy poszukiwanie rady lub pomocy w odgrywaniu pewnych ról społecznych. Przekaz informacji to jeden z warunków komunikacji, zaś jej jakość decyduje o komunikacji pomiędzy nadawcą i odbiorca komunikatu. Komunikat dostarczany przez informację jest opisem pewnego 
wycinka rzeczywistości. Infologiczna koncepcja informacji subiektywnej uzależnia odbiór i interpretację komunikatu od odbiorcy. Treść informacji będąca opisem pewnego wycinka rzeczywistości, pozwala odbiorcy na poznanie nowej rzeczywistości, zdobycie nowej lub zweryfikowanie dotychczasowej wiedzy oraz ocenę lub zmianę posiadanych poglądów na obserwowane zjawiska [Stefanowicz: 2004: 20]. I choć odwzorowanie treści informacji przez odbiorcę uzależnione jest od wielu czynników, w tym od wiedzy i doświadczenia, to o jakości informacji decyduje nadawca. Zakres treści prezentowanych w Internecie, zależy głównie od twórcy informacji, jego wiedzy, odpowiedzialności i rzetelności, jak również od sprawności w posługiwaniu się tym narzędziem. I to właśnie organizacjom sektora publicznego, jako twórcom informacji, przypada szczególna rola. Należy przypomnieć, iż obywatel ma konstytucyjne prawo do dostępu do informacji publicznej.

Wiarygodność jest wartością postrzeganą i ocenianą na zewnątrz organizacji, którymi w tym przypadku są instytucje administracji publicznej. Każda informacja, która jest nieaktualna, wprowadzająca w błąd interesariuszy (obywateli), podważa jej wiarygodność i powszechnie wpływa na zaufanie. Zwłaszcza jeżeli informacje te występują w Internecie, medium dostępnym i popularnym. Wizerunek może dotyczyć osób lub organizacji, którą przedstawia w korzystnym świetle, służąc zdobywaniu społecznej akceptacji dla własnej działalności, tym samym pozyskując coraz większe rzesze klientów lub sympatyków [Altkorn: 2004: 14].

Wizerunek nie ma charakteru stałego i może ulegać ciagłym zamianom i modyfikacjom. Utrzymanie pozytywnego wizerunku organizacji wymaga zatem ciaggłych starań i wysiłków związanych z aktywnym budowaniem jej tożsamości. Organizacja powinna zdawać sobie sprawę z korzyści, jakie niesie za sobą pozytywny, jednolity obraz w świadomości klientów. Silny i pozytywny wizerunek organizacji pozwala na utrzymanie obecnych oraz na przyciagnięcie nowych klientów.

Obok pojęcia wizerunku pojawia się także inny termin, a mianowicie osobowość organizacji (corporate personality). Wykorzystywanie pojęcia osobowości dla budowania organizacji wynika z przekonania, że podobnie jak ludzie, ujawniają one „cechy charakteru”, których konsekwencją jest skłonność do określonych reakcji. Personifikacja sprzyja zatem bardziej wyrazistemu postrzeganiu organizacji. Wizerunek jest wypadkową działań organizacji oraz cech osób, do których działania te są adresowane. Wizerunek jest to pewne wrażenie całości powstające na tle kontaktu z jakimś produktem lub usługą. Łączenie znaczeń tych dwóch wyżej wymienionych pojęć sprzyja bardziej wyrazistemu postrzeganiu organizacji.

Wizerunek organizacji kształtuje się w wyniku zetknięcia się uczestników otoczenia z czynnikami charakteryzującymi tę organizację. Wynikiem tego są wszystkie doświadczenia, oczekiwania, uczucia, wiedza oraz wrażenia, które 
uczestnicy otoczenia wiążą z daną organizacją. Nabywcy usługi postrzegają organizację odpowiednio interpretując docierające do nich bodźce poprzez odbiór selektywnych komunikatów. Proces postrzegania charakteryzuje się jednak wybiórczością, a o tym co przeniknie do świadomości odbiorców tychże komunikatów, będą decydowały ich postawy, uznawane wartości, motywy, określona sytuacja czy aktualne zainteresowania. Percepcja komunikatów dotyczących organizacji (marek, produktów) prowadzi do powstawania określonych o niej wyobrażeń i ocen [Black: 1999: 96].

Kształtowanie wizerunku organizacji należy traktować jako proces, w którym myśli, wyobrażenia, odczucia oraz doświadczenia z nią wiązane zostają poddane kategoryzacji przez uczestników otoczenia. Wizerunek organizacji można zatem określić jako obraz danej instytucji w opinii otoczenia, ukształtowany na podstawie jej świadomych i nieświadomych działań. Bardzo ważną rolę przy poddaniu kategoryzacji odczuwanych bodźców mają potrzeby i oczekiwania poszczególnych uczestników otoczenia organizacji. Do podstawowych funkcji wizerunku organizacji zaliczyć należy:

- przyczynianie się do budowy zaufania do określonej organizacji i jej usług,

- kształtowanie pozytywnych relacji miedzy organizacją i jej otoczeniem,

- stanowienie głównego czynnika wyboru marki produktu, dostawcy przez nabywcę.

Docierając do uczestników otoczenia bodźce mogą mieć charakter bezpośrednich kontaktów, a także wynikać z opinii na temat postrzeganej organizacji wyrażanej przez inne jednostki. W przypadku petentów docierające bodźce prowadzące do powstania spostrzeżeń, a następnie wyobrażeń mają szczególne znaczenie w przypadku procesów podejmowania decyzji, szczególnie w czasie wyborów (samorządowych, parlamentarnych).

\section{Prawo do informacji w Polsce}

W Konstytucji Rzeczypospolitej Polskiej w rozdziale II. Wolności, Prawa i Obowiązki Człowieka i Obywatela w art. 61 wskazano, że: Obywatel ma prawo do uzyskiwania informacji o działalności organów władzy publicznej oraz osób petniacych funkcje publiczne. (...) Prawo do uzyskiwania informacji obejmuje dostęp do dokumentów (...) [Konstytucja Rzeczypospolitej Polskiej z dnia 2 kwietnia 1997 r.], co oznacza, że każdy ma prawo dostępu do nich za pomoca środków elektronicznych. Ustawą precyzującą zasady korzystania z tego prawa jest ustawa o dostępie do informacji publicznej [Ustawa z dnia 6 września 2001 r.] ogłoszona na podstawie art. 61 Konstytucji Rzeczpospolitej Polskiej. Ustawa wymienia tryb ogłaszania informacji publicznych, w tym dokumentów urzędo- 
wych, w Biuletynie Informacji Publicznej (BIP) będącym ogólnodostępnym portalem internetowym, o którym mowa w art. 8 ust. 1 ustawy [ibidem]. BIP to portal służący powszechnemu i bezpłatnemu dostępowi do informacji publicznej, zarówno poprzez stronę główną biuletynu, jak i strony podmiotowe, przygotowane przez podmioty ustawowo zobowiązane do ich prowadzenia. Do tworzenia podmiotowych stron BIP zobowiązane są $\mathrm{m}$. in.: organy władzy rządowej i samorządowej, państwowe i samorządowe osoby prawne oraz jednostki organizacyjne oraz inne podmioty wykonujące zadania publiczne. Standardy dla BIP określa rozporządzenie $\mathrm{w}$ sprawie minimalnych wymagań dla systemów teleinformatycznych [Rozporzq̨dzenie Rady Ministrów z dnia 11 października 2005 r.], które obowiązuje od wejścia w życie Ustawy o informatyzacji działalności podmiotów realizujących zadania publiczne [Ustawa $z$ dnia 17 lutego 2005 r.] Ustawa uchyliła poprzednie rozporządzenie w sprawie BIP [Rozporzqdzenie Ministra Spraw Wewnętrznych i Administracji z dnia 17 maja 2002 r.]. Systemy teleinformatyczne powinny spełniać właściwości i cechy w zakresie funkcjonalności, niezawodności, używalności, wydajności, przenoszalności i pielęgnowalności na etapie projektowania, wdrażania i modyfikowania tych systemów, umożliwiające wymianę danych $\mathrm{z}$ innymi systemami teleinformatycznymi używanymi do realizacji zadań.

Administracja publiczna ma tworzyć fundamenty społeczeństwa informacyjnego, lub jak to często jest formułowane gwarantować rozwój społeczeństwa informacyjnego w Polsce, a rola administracji publicznej online, to służenie obywatelom poprzez swoja dostęność, poufność, wiarygodność i jakość - jednakowo na terenie całej Polski oraz w powiazaniu z zasobami informacyjnymi innych krajów [e-Polska - Plan działań na rzecz rozwoju społeczeństwa informacyjnego w Polsce na lata 2001-2006: 2001]. W następnych latach wydano kolejne dokumenty strategiczne, włącznie ze Strategiq rozwoju społeczeństwa informacyjnego w Polsce do roku 2013. Rząd deklaruje:

Rozwojowi spoteczeństwa informacyjnego $w$ Polsce powinny trwale towarzyszyć:

- Dostepność, bezpieczeństwo i zaufanie - możliwość uzyskania dostęu do rzetelnej informacji lub bezpiecznej ustugi niezbędnej obywatelowi oraz przedsiębiorcy.

- Otwartość i różnorodność - brak preferencji i brak dyskryminacji $w$ dostępie do informacji, a w szczególności do informacji publicznej.

- Powszechność i akceptowalność - dażenie, aby udziat w dobrach społeczeństwa informacyjnego byt oczywisty i jak najszerszy, a także by oferta produktów i usług społeczeństwa informacyjnego była maksymalnie szeroka.

- Komunikacyjność i interoperacyjność - zapewnienie dotarcia do pożądanej informacji w sposób bezpieczny, szybki i prosty [Strategia rozwoju społeczeństwa informacyjnego w Polsce do roku 2013: 2008: 9]. 
Mimo tych deklaracji w Polsce do tej pory brak uregulowań prawnych dotyczących standardów jakościowych dla stron internetowych i jest to jednym z powodów, dla których administracja publiczna nie czuje się zobligowana do stosowania zaleceń i korzystania z dobrych praktyk. Etyka i kompetencje pracowników organizacji administracji publicznej powinny być warunkiem wystarczającym do przestrzegania prawa w zakresie dostępu do informacji w Polsce, a także do dbałości o jakość treści informacji.

Często przypisuje się a priori wysoką wiarygodność źródeł informacji stron rządowych. Tak jednak nie jest, czego dowodem są badania jakości informacji prezentowanych $\mathrm{w}$ wybranych portalach internetowych sektora administracji publicznej [szerzej: Batko: 2008b: 211-227; Batko: 2008c: 348-359; Batko: 2009a: 169-177; Batko: 2009b: 49-67 i inne].

\section{Jakość informacji internetowej w administracji publicznej}

Informacje mogą być z jednej strony źródłem wiedzy, inspiracją do nowych działań i pomocą $\mathrm{w}$ rozwiązywaniu szeregu problemów, $\mathrm{z}$ drugiej zaś strony informacja fałszywa buduje fałszywą wiedzę, a nieumiejętnie odczytana i użyta przez odbiorcę może być zagrożeniem, ponieważ prowadzi do skutków niepożądanych.

Z punktu widzenia odbiorcy informacji - użytkownika, najistotniejsza jest praktyczna użyteczność prezentowanych informacji, na którą wpływa szereg cech, w tym jakość informacji budująca jej wartość. Jakość jest odbierana subiektywnie i zależy od potrzeb odbiorcy. Infologiczna interpretacja pojęcia informacji koncentruje się na informacji jako treści dostarczonej przez komunikat. Można więc zweryfikować użyteczność informacji w procesie zbierania i przetwarzania treści w określoną wiedzę, poprzez badania wybranych cech informacji [Stefanowicz: 2004: 11]. Spośród wielu zdefiniowanych w literaturze cech jakościowych informacji, do najważniejszych cech wpływających na treść informacji można zaliczyć [ibidem: 101-107; Miller: BDP]:

- aktualność informacji, rozumianą jako dostateczna zgodność informacji ze stanem rzeczywistym obiektu. Na obniżenie poziomu tej cechy wpływa czas;

- dokładność informacji określająca jej adekwatność względem poziomu wiedzy odbiorcy;

- jednoznaczność informacji zależną od zastosowania jednoznacznego języka oraz precyzyjnie zdefiniowanych pojęć;

- kompletność informacji - teoretycznie dotyczy wszystkich informacji opisujących obiekt, w praktyce warunek niemożliwy do spełnienia wobec niewyczerpalności informacji. Wystarczalność to taka ilość informacji, które pozwolą na podjęcie racjonalnej decyzji w konkretnej sytuacji; 
- komunikatywność (zrozumiałość) informacji, cecha pozwalająca na przyjęcie informacji bez specjalnych, dodatkowych zabiegów związanych z interpretacją semantyczną treści komunikatu oraz

- relewantność informacji, czyli trafność czy też stopień zbliżenia do problemu, z jakim użytkownik ma do czynienia;

- rzetelność informacji, uzależniona od metody zbierania informacji, poprawności określenia stosowanych pojęć, definicji, klasyfikacji i innych czynników ważnych przy gromadzeniu i przetwarzaniu informacji. Opisuje ona powody, dla których informacja jest mniej lub bardziej dokładna;

- spójność - czy poszczególne elementy, dane współgrają ze sobą, forma odpowiada treści, aktualizacja danych jest zgodna z celami, jakim służy gromadzenie informacji.

Oceny jakości informacji sieciowej dokonać można jedną ze stosowanych metod oceny strony WWW tzw. metodą jakościowo-heurystyczną, inaczej ekspercką. W metodzie tej stosuje się kryteria oceny tworzone od 1994 r. przez organizację W3C (World Wide Web Consortium). Inicjatywa o nazwie Dostępność Sieci (The Web Accessibility Initiative) pozwoliła na opracowanie wytycznych, w tym zaleceń dotyczących Dostępności Zawartości Sieci (The Web Content Accessibility), będących de facto obowiązującymi na całym świecie standardami do tworzenia witryn internetowych [szerzej: Batko: 2008a: 22-27]. Metoda ekspercka proponuje procedury twórcze oceny, zatem nie daje gwarancji znalezienia optymalnego rozwiązania problemu. W przypadku treści informacji będzie to merytoryczna ocena jej jakości. Trudność w ocenie jakości informacji polega na tym, iż wartość informacji jest uzależniona od swoistych cech odbiorcy, w tym jego wiedzy, a więc może nie być w pełni obiektywna [Tadeusiewicz: 2002: 17].

W toku badań jakości treści informacji wielu portali internetowych organizacji administracji publicznej, zauważono bardzo niską jakość publikowanych treści, które stają się całkowicie nieprzydatne dla odbiorcy. Zamieszczenie wszystkich przykładów przekroczyłoby ramy niniejszego artykułu, dlatego też ograniczono się do przykładu badania witryny internetowej Urzędu Komitetu Integracji Europejskiej, które przeprowadzono 30 kwietnia i 10 maja 2010 r. Komitet Integracji Europejskiej utworzony został 1 października 1996 r. Był naczelnym organem administracji w zakresie koordynacji i programowania polityki integracji Polski z UE. 1 stycznia 2010 r. Urząd Komitetu Integracji Europejskiej połączył się z Ministerstwem Spraw Zagranicznych. Od tej pory realizacją zadań europejskich zajmuje się nowo powstały Komitet do Spraw Europejskich. Informacje o UKIE funkcjonują jeszcze pięć miesięcy po zlikwidowaniu organizacji.

Na stronie podmiotowej UKIE u góry i po lewej stronie znajdują się wyszukiwarki tematyczne (menu przedmiotowe) zgrupowane w 9 obszarach tematycznych rozwijających się w informacje zawarte na kolejnych podstronach witryny 
UKIE. Są to: Przewodniczący KIE, KERM/KIE, UKIE, Serwis prasowy oraz Prawo, Wybór dokumentów, UE w pigułce, Źródła informacji o UE, Obszary tematyczne oraz link do strony BIP UKIE. Każdy z nich zawiera od kilku do kilkunastu podstron szczegółowych. Ponieważ organizacja nie istnieje od 5 miesięcy, należałoby wyczerpująco informować odwiedzającego tę stronę, iż ma do czynienia z jej archiwalna strukturą i materiałem archiwalnym. Chcąc więc rzetelnie informować odbiorcę odwiedzającego portal, należałoby na każdej z podston zamieścić czytelną i widoczną notatkę. Pomijając szczegółowy opis zawartości każdej z podstron, w toku badania można było stwierdzić, iż ponad połowa informacji jest pozbawiona dwóch głównych cech znamionujących jakość informacji: jej aktualności i rzetelności. W czasie badania 81 stron witryny UKIE:

- strona główna - posiada informację o połączeniu z dniem 1 stycznia $2010 \mathrm{r}$. Urząd Komitetu Integracji Europejskiej z Ministerstwem Spraw Zagranicznych i przeniesieniu strony oraz automatyczne przekierowanie po 7 sekundach na nową stronę MSZ;

- strona - BIP UKIE - posiada informację o połączeniu z dniem 1 stycznia 2010 r. Urząd Komitetu Integracji Europejskiej z Ministerstwem Spraw Zagranicznych bez podania nowego adresu strony i bez przekierowania na nową stronę MSZ;

- strona - Serwis prasowy UKIE - informacja o połączeniu z dniem 1 stycznia 2010 r. Urząd Komitetu Integracji Europejskiej z Ministerstwem Spraw Zagranicznych;

- 39 stron - brak informacji o tym, że strona jest archiwalna; na 28 stronach brak dat utworzenia informacji;

- 35 stron - brak daty zamieszczenia informacji, ale z informacją, że strona jest archiwalna, bez wyjaśnienia przyczyn;

- 2 strony - nie otwierają się;

- 1 strona - posiada załączniki bez dat utworzenia;

- 1 strona - posiada załączniki - wersję roboczą dokumentu KE z 2003 r.

Reasumując, z 81 stron witryny UKIE:

- 3 strony - posiadają informację o archiwizacji strony, z wyjaśnieniem przyczyn;

- 35 stron - posiadają informację o archiwizacji strony, bez wyjaśnienia przyczyn;

- 43 strony - nie podają informacji o archiwizacji strony.

Inna strona publiczna Biuletynu Informacji Publicznej informuje o (aktualnie funkcjonującym) Urzędzie Komitetu Integracji Europejskiej w spisie podmiotów, jako jednym z Urzędów Podległych i Nadzorowanych Przez Ministrów. Zamieszczono tu informacje adresowe, mailowe i telefoniczne, link do strony UKIE oraz mape z notatką: Lokalizacja podmiotu jest przybliżona. Redakcja strony głównej BIP nie gwarantuje jej zgodności z rzeczywistościq. Strona nie 
ma daty zamieszczenia informacji [Urząd Komitetu Integracji Europejskiej: 10 maja 2010]. Link do strony podmiotowej UKIE łączy ze stroną <www.bip.ukie.gov.pl>, gdzie zamieszczono kolejną informację: Próbujesz odwiedzić adres http://www.bip.gov.pl/subjects/url/4519, który jest w tej chwili niedostępny [Błąd! Nie można odnaleźć serwera: 10 maja 2010].

Problemem dla poszukującego szczegółowej informacji jest to, iż po wpisaniu hasła w wyszukiwarkę, nie zostanie on skierowany na stronę główną, tylko do konkretnej podstrony portalu skojarzonej z wyszukiwanym hasłem, tak więc prawdopodobieństwo trafienia na błędną informację jest bardo wysokie $(0,53)$. To jeden z wielu przykładów działań informacyjnych organizacji sektora publicznego.

\section{Podsumowanie}

Wiele portali internetowych administracji publicznej zamieszcza nieprawdziwe treści, przede wszystkim zdezaktualizowane, niekompletne, nierzetelne, niejednoznaczne i przekazane w sposób niekomunikatywny, usiane błędami językowymi. Brak im jednoznaczności, ponieważ często są ze sobą sprzeczne. Są też treści redundantne. Niejednokrotnie osoby lub instytucje, do których adresowane są portale mają do dyspozycji informacje złej jakości. Są one fałszywe - zjawisko często obserwowane w odniesieniu do zdezaktualizowanych przepisów prawnych, czy pewnych procedur postępowania. Informacje pozbawione są daty zamieszczenia, tym bardziej daty modyfikacji, autora notatki, źródeł, z których zaczerpnięto prezentowane treści. Nieaktualne są również te informacje, które byłyby pomocne w dalszym poszukiwaniu, w tym linki do stron o tematyce uzupełniającej wiedzę lub pokrewnej. Bardzo często te strony internetowe pod wskazywanym adresem nie istnieją. Należy zaznaczyć, że osoby uczące się nie są w stanie ocenić prawdziwości podanych informacji, zaś osoby mające na ten temat wykształconą już wiedzę, potrzebują kilku, a nawet kilkunastu godzin na rzetelne zweryfikowania treści. Tak prowadzone portale świadczą o nieodpowiedzialności organizacji podających informacje. Budowanie wiedzy w oparciu o takie treści jest niemożliwe, a nawet szkodliwe, ponieważ działania te noszą znamiona dezinformacji.

W dobie unifikacji prawa w państwach Unii, powszechnego dokonywania ocen przez interesariuszy, informację przekazywaną na zewnątrz musi charakteryzować właściwa jakość. Świadczy o niej zarówno forma, jak i treść, w tym m. in. takie cechy jak aktualność, zgodność z prawem, prostota i komunikatywność formy. Jakość tę powinni tworzyć pracownicy administracji publicznej.

Pracownicy administracji publicznej muszą być więc odpowiedzialni za swoje decyzje, w tym za umieszczanie informacji w portalach internetowych. Odpowiedzialność musi być tu rozpatrywana zarówno w kontekście etycznym, 
jak i prawnym. Należy właściwie rekrutować kadrę i szkolić ją, aby wzbudzać indywidualne poczucie odpowiedzialności jako elementu etosu pracy w administracji publicznej. Z drugiej strony należy bezwzględnie sankcjonować te zachowania poprzez dokonywanie bieżącej oceny i eliminowanie nieodpowiedzialnych pracowników. Niezbędne wydaje się tu nie tylko pilne stworzenie prawnej wykładni w formie kodeksu etycznego pracowników administracji publicznej, ale i stosowanie jego zapisów.

\section{Bibliografia:}

Altkorn Jerzy W, 2004, Wizerunek firmy, Wyższa Szkoła Biznesu w Dąbrowie Górniczej, Dąbrowa Górnicza.

Batko Barbara, 2008a, Chapter 2. Quality Criteria For Public Sector Websites in Poland, [w:] L. Jeziorski, S. Borkowski (red.), Zarzqdzanie, doskonalenie, zmiany. Monografia, Oficyna Wydawnicza Humanitas, Sosnowiec.

Batko Barbara, 2008b, Internetowe źródta informacji o rynku pracy a konkurencyjność przedsiębiorstw trzeciego sektora, [w:] Administracja i zarzadzanie, Zeszyty Naukowe Akademii Podlaskiej, nr 78, Numer specjalny (5) 2008, Wydawnictwo Akademii Podlaskiej, Siedlce.

Batko Barbara, 2008c, Jakość informacji dotyczqcych rynku pracy upowszechnianych za pomoca Internetu przez instytucje publiczne, [w:] E. Pancer-Cybulska (red.), Gospodarka spoteczna w Europie, Monografie Wyższej Szkoły Handlowej we Wrocławiu, Wrocław.

Batko Barbara, 2009a, Jakość informacji publikowanych w Internecie jako wartość wptywajaca na wiarygodność instytucji, [w:] Baryluk M., Wawrzak-Chodaczek M., Wartości w komunikacji różnych grup społecznych, Wydawnictwo Adam Marszałek, Toruń.

Batko Barbara, 2009b, Zarzqdzanie jakościq informacji w sektorze publicznym a bezpieczeństwo spoteczeństwa, [w:] Włodarczyk M., Marjański A., Bezpieczeństwo i zarzqdzanie kryzysowe - aktualne wyzwania. Zagrożenie bezpieczeństwem $w$ sektorze publicznym, t. X, Z. 8, Wydawnictwo Społecznej Wyższej Szkoły Przedsiębiorczości i Zarządzania w Łodzi, Łódź.

Black Sam, 1999, Public Relations, Warszawa.

Boć Jan (red.), 2003, Administracja publiczna, Kolonia Limited, Wrocław.

Dubisz Stanisław (red.), 2003, Uniwersalny stownik języka polskiego, t. 1: A-J PWN, Warszawa.

e-Polska - Plan działań na rzecz rozwoju społeczeństwa informacyjnego w Polsce na lata 2001-2006, Ministerstwo Gospodarki, aktualizacja 11.09.2001 [online], Urząd Komitetu Integracji Europejskiej, http://www1.ukie.gov.pl/ HLP/files.nsf/0/99094766263E249EC1256E8400314623/\$file/ePolska.doc (dostęp 15 stycznia 2008). 
European Ombudsman, 2002, The European Code of Good Administrative Behaviour, Luxembourg: Office for Official Publications of the European Communities, March.

Gasparski Wojciech, 2000, Kodeksy etyczne: ich projektowanie, wprowadzanie i stosowanie (na wybranym przyktadzie), „Annales”, t. 3 [online]; http://cebi.pl/texty/Kodeks_kazus.doc (dostęp: 17 kwietnia 2010).

Goban-Klas Tomasz, 2001, Media i komunikowanie masowe, PWN, WarszawaKraków.

Izdebski H., 2007, Od administracji publicznej do public goverance, „Zarządzanie Publiczne", nr 1.

Izdebski Hubert, 2010, Zasady i etyka w stużbie cywilnej, „Przegląd Służby Cywilnej”, Departament Służby Cywilnej Kancelarii Prezesa Rady Ministrów, nr 2(5) [online]; http://www.dsc.kprm.gov.pl/userfiles/PSCmarzec_ kwiecien2010(1).pdf (dostęp: 15 kwietnia 2010).

Kettl Donald F., 2000, The Global Public Management Revolution. A Report on the Transformation of Governance, The Brookings Institution, Washington.

Konstytucja Rzeczypospolitej Polskiej z dnia 2 kwietnia 1997 r., DzU 1997, nr 78, poz. 483.

Kowalczyk Lucjan, 2008, Wspótczesne zarzqdzanie publiczne jako wynik procesu zmian w podejściu do administracji publicznej, Zeszyty Naukowe Wałbrzyskiej Wyższej Szkoły Zarządzania i Przedsiębiorczości, nr 1 [online]; http://www.lucjankowalczyk.com/wp-content/uploads/2008/10/59-2.pdf (dostęp: 2 lutego 2010).

Krajewski Wojciech, 2000/2001, Etyka w stużbie publicznej. Uregulowania prawne dotyczqce etyki w stużbie publicznej w Polsce, „Służba Cywilna” nr 1.

Miller Holmes, BDP, The multiple dimensions of information quality. Information System Management [online]. Muhlenberg College's Department of Accounting, Business and Economics, Allentown, Pennsylvania; http://www.muhlenberg.edu/depts/abe/business/miller/mdiqual.html (dostęp 5 lutego 2008).

Rozporzadzenie Ministra Spraw Wewnętrznych i Administracji z dnia 17 maja 2002 r. w sprawie Biuletynu Informacji Publicznej, DzU 2002, nr 67, poz. 619.

Rozporzqdzenie Rady Ministrów z dnia 11 października 2005 r. w sprawie minimalnych wymagań dla systemów teleinformatycznych, DzU 2005, $\mathrm{nr} 212$, poz. 1766.

Stefanowicz Bogdan, 2004, Informacja, Wyd. 1, SHG, Warszawa.

Strategia rozwoju spoteczeństwa informacyjnego $w$ Polsce do roku 2013, MSWiA, Warszawa 2008 [online]; http://www.mswia.gov.pl/ download.php?s=4\&id=3760 (dostęp: 29 kwietnia 2010). 
Strategiczny plan rzqdzenia [online], Kancelaria Prezesa Rady Ministrów; http://www.kprm.gov.pl/templates/admin/userfiles/ files/1983_prezentacja_ kprm.swf (dostęp 22 sierpnia 2008).

Tadeusiewicz Ryszard, 2002, Spoteczność Internetu, Akademicka Oficyna Wydawnicza Exit, Warszawa.

Tokarski Jan (red.), 1980, Stownik wyrazów obcych, PWN, Warszawa.

Urzad Komitetu Integracji Europejskiej [online]. Biuletyn Informacji Publicznej; http://www.bip.gov.pl/subjects/4519,Urząd+ Komitetu++Integracji+ Europejskiej.html(dostęp: 10 maja 2010).

Ustawa z dnia 17 lutego 2005 r. o informatyzacji działalności podmiotów realizujacych zadania publiczne, DzU 2005, nr 64, poz. 565.

Ustawa z dnia 18 grudnia 1998 r. o stużbie cywilnej, DzU 1999, nr 49, poz. 483.

Ustawa z dnia 21 listopada 2008 r. o stużbie cywilnej, DzU ..., $\mathrm{nr} 227$, poz. 1505.

Ustawa z dnia 24 sierpnia 2006 r. o stużbie cywilnej, DzU 2006, nr 170, poz. 1218.

Ustawa z dnia 6 września 2001 r. o dostępie do informacji publicznej, DzU 2001, nr 112, poz. 1198.

Załącznik do Zarzadzenia $n r 114$ Prezesa Rady Ministrów z 11 października 2002 r. sprawie ustanowienia Kodeksu Etyki Stużby Cywilnej, M.P. nr 46, poz. 683.

Zarzqdzenie nr 114 Prezesa Rady Ministrów z 11 października 2002 r. sprawie ustanowienia Kodeksu Etyki Stużby Cywilnej, M.P. nr 46, poz. 683.

Zoll Andrzej, 2002, Prawo do dobrej administracji (przedmowa do I wydania Rzecznika Praw Obywatelskich IV kadencji), Warszawa, październik [w:] Świątkiewicz J., 2007, Europejski Kodeks Dobrej Administracji (wprowadzenie, tekst $i$ komentarz o zastosowaniu kodeksu $w$ warunkach polskich procedur administracyjnych), Wydanie VI, Biuro Rzecznika Praw Obywatelskich, Warszawa, marzec.

\section{RESPONSIBILITY OF PUBLIC ADMINISTRATION STAFF IN THE PROCESS OF BUILDING AN INFORMATION SOCIETY IN POLAND}

\section{Summary}

The Polish state emphasises the importance of transforming the industrial society into a modern innovative one. The term information society was adopted in EU official documents in the mid-1990s. The activities of the Polish state undertaken in order to build and develop an information society have a ten-year tradition. A big role in the effectiveness of these activities is played by the sense of a special mission fulfilled by public service and responsibility of public sector employees. 
The article, from the angle of ethical values, rules of conduct and professionalism, attempts to evaluate the effectiveness of activities undertaken by public administration staff in managing the quality of information published by public sector organizations on the Internet.

Key words: public administration, information society, code of ethics, quality of information, Internet. 